\title{
MODELING OF SUSPENDED MATTER DISTRIBUTION IN MARINE COASTAL AREAS: 2. TESTING AND PRACTICAL APPLYING OF SM-MODEL
}

\author{
K.A. Podgornyi ${ }^{1}$, A.V. Leonov ${ }^{2}$ \\ ${ }^{1}$ Atlantic Research Institute for Fisheries and Oceanography \\ ul.Dm. Donskoy, 5. Kaliningrad, 236000. Russia, e-mail: kapborok@mail.ru \\ ${ }^{2}$ Shirshov Institute of Oceanology, Russian Academy of Sciences, 36, Nakhimovskyi prosp., \\ Moscow, 117997, Russia, e-mail: leonov@,ocean.ru \\ Submitted 05.09.2017, accepted 25.12.2017
}

\begin{abstract}
The application of the developed model is shown. It describes the consequences of dredging in the coastal waters (the formation of turbidity spots and the spread of suspended matter over the water area) as well as calculates the values of several parameters characterizing the conditions for the redistribution of suspended matter in the water column and on the bottom surface. These parameters include the duration of the turbidity spot in the water, the change and distribution of the concentration of suspended matter within such a spot, and the accumulation of losses of suspended matter at the bottom for the entire period of work. These parameters are included in the list of characteristics on the base of which damage to biological resources (for example, to benthic organisms) is estimated due to disturbances in their natural habitat after completion of works on bypassing.
\end{abstract}

Keywords: bypassing; model of suspended matter distribution; information for calculations on the model: natural factors (wind, sea currents, temperature and salinity of sea water, properties of sandy bottom sediments); technological data of carrying out dredging works; calculations of ground losses, conditions for the formation of suspended matter, its concentration in water, accumulation at the bottom.

\section{Introduction}

Testing the model (selection of empirical parameters, its tuning) is an independent stage of its approbation which involves the use of appropriate observational data. It is intended to test the model (and perform calculations) for the coastal waters of the Baltic Sea for which no preliminary studies on the distribution of turbidity zones have been carried out. However, a certain experience of verification of individual model blocks is available for other water bodies. For example, in the modeling of thermo-hydrodynamic processes, a comprehensive check of operability and mutual consistency of calculations performed with the help of hydrodynamic, thermo-hydrodynamic and hydrobiological modules. A similar procedure for testing of the model has applied for the whole Rybinsk Reservoir and its individual stretches as well as for the Neva Bay Gulf of Finland (Podgornyi, 2009a,b, 2012; Podgornyi, Poddubnyi, 2005, 2009; Poddubnyi, Podgornyi, 2009; Podgornyi, 2010). 
The model testing showed that the non-stationary hydrodynamic model can be effectively used not only for solving of hydrological problems themselves, but also for numerical integration of system of the thermo-hydrodynamic and hydrobiological equations in the simulation models of the Rybinsk Reservoir's aquatic ecosystem as well as the HTD-NPmodel (Neva Bay). Similar methodology is useful for long periods with the possibility to take into account the intra-annual variability of the meteorological and hydrological conditions, and changes in the water and external biogenic load on the water body.

Verification (non-stationary hydrodynamic model based on observations of flow parameters) showed that the discrepancy between calculated and actual flow velocities at the Rybinsk Reservoir polygons usually does not exceed the error of their measurement (on average 15-20\%). Calculations of the current structure in the Neva Bay (Gulf of Finland) showed a good qualitative and quantitative correspondence to the main observable features of the formation of the space-temporal structure of the currents in this water body. The hydrodynamic block of the model designed to reproduce the intraannual variability of the flow fields for the period of open water, if necessary, can take into account the changes in water flow rates of rivers (or hydro-meteorological conditions for the water body). Testing has shown that these model blocks may use as a basis for the subsequent modeling of the space-temporal variability of a number of variables (water temperature, individual components of the ecosystem, distribution of suspended and dissolved substances in water environment).

The purpose of the research is to provide practical information on the application of the developed SM-model to assess the consequences of dredging or the formation and redistribution of SM in the marine offshore area. As an example of using the modeling methodology, we will review the available information, prepare the data necessary for the calculation, and estimate the values of a number of empirical coefficients for solving the problem: modeling the process of spreading SM in marine coastal waters during dredging (by the example of the coastal section of the Baltic Sea).

\section{Data required for performing of calculations on SM-model}

To perform calculations on the SM-model, a considerable number of different initial data are required to assess the ecological consequences of work on bypassing influencing the water environment and the habitat of aquatic biological resources. We will perform some sorting of the required data. This will allow user to orient yourself in who, how and where such raw data to collect for similar calculations. Firstly, we make some subdivision of this information into separate groups:

- data for the description of the coastal marine area where work on bypassing is proposed to carry (location of the work area, its boundaries, average and maximum depths, area of the entire site and the immediate area of bypassing work);

- information that characterizes the natural marine environment; it includes data on the hydro-meteorological and hydrological parameters affecting the propagation of SM in the marine environment (depth maps, data on the direction and speed of the wind and 
on the most characteristic features of the space-temporal structure of the currents, the temperature $T_{w}$ and salinity $S_{w}$ of the sea waters;

- data on sandy material in bottom sediments in the work area (granulometric composition, its physical and mechanical properties);

- technological data that determine the conditions for performing work on bypassing (operational characteristics of the work, the scheme of work, the technical characteristics of the vessel and the equipment used for sampling, loading and moving the sediments, the application of which leads to the appearance and spread of the turbidity spot in the coastal zone - in the work area and in adjacent water areas);

- empirical information: a variety of calculated dependencies, correlation relationships that describe the interconnection of oceanological parameters (wind flow characteristics, waves) and the conditions for the SM redistribution; empirical relationships that allow us to estimate the rates of SM sedimentation and the resuspension of the bottom sediments by the values of factors/parameters of the marine environment (wind, waves, current velocities, etc.); values of numerous empirical parameters/coefficients. As a rule, additional studies and test calculations are always required to refine the dependencies and values of the coefficients since there are no universal dependencies for calculating the effect of oceanological parameters (in particular, waves and currents) on the bottom of the water bodies. In this case, both the empirical coefficients of the calculated dependences and the number of considered water flow regimes can differ, as well as the quantitative criteria for their isolation. All this leads to the fact that in the model intended for calculating the propagation of SM, it is necessary to envisage the use of different methods for calculating the values of the hydrodynamic effect on the processes of SM sedimentation and resuspension of the bottom sediments and their possible refinement at the stage of parametric adjustment of the model.

Usually the initial information specified in sections (1.1)-(1.4) is prepared and provided by the organization (or the Customer) which plans to work bypassing and implements them in practice, and the empirical information of section is obtained at the working with the model (debugging, model calibration and execution of actual calculations on the model).

\subsection{Description of the work area for bypassing}

The proposed area of the work is the coastal zone of the Baltic Sea (Kaliningrad region - from the Taran Cape to the $48 \mathrm{~km}$ of Curonian Spit) with a width of $500 \mathrm{~m}$ from the water edge towards the shore and to a depth of $30 \mathrm{~m}$ towards the sea. The average depth of the water area is $27.5 \mathrm{~m}(26-29 \mathrm{~m})$, the area of the site is $2.62 \mathrm{~km}^{2}$. In this area (depths of 15-30 m) sand can be extracted for artificial washing up beaches in the Kaliningrad region.

On this section of the Baltic Sea, a monitoring area (MA) was identified in the immediate vicinity of the D-6 platform and a section of the underwater coastal slope (UCS). 
The amount of dredging works (moving the ground) under the project is assumed equal to 2.100 thousand $\mathrm{m}^{3}$, the area of damage to the bottom when sand is extracted to a depth of $1.5 \mathrm{~m}$ will be at the landfill of 182 hectares (the site will be passed twice, as at one time a layer of sandy soil extracted is $75 \mathrm{~cm}$ ).

\subsection{Information characterizing the natural marine environment}

Approximate work period of dredging is from June to October (with a total duration - 180 days). The influence of the natural environment on the processes associated with the formation, distribution and redistribution of SM in the marine environment primarily depends on natural oceanological factors. These include wind, sea currents, temperature and salinity of sea waters, and bottom sediments.

Wind. The data of long-term observations (Kaliningrad point) show that the temperate winds of the south-western and western directions prevail over the area in the indicated period (fig. 1). Average monthly wind speeds for these months vary within $3.5-5.5 \mathrm{~m} / \mathrm{sec}$, and average wind speeds for the whole work period, summer, and autumn, are $4.0,3.9$, and $4.1 \mathrm{~m} / \mathrm{sec}$, respectively. The recurrence of days with a calm in JuneAugust and September-October is 11.9 and $11.5 \%$, respectively (fig. 2). Note that the data obtained at the coast station of meteorological observations, and they can not quite correspond to data on the wind above the sea surface in the work area.

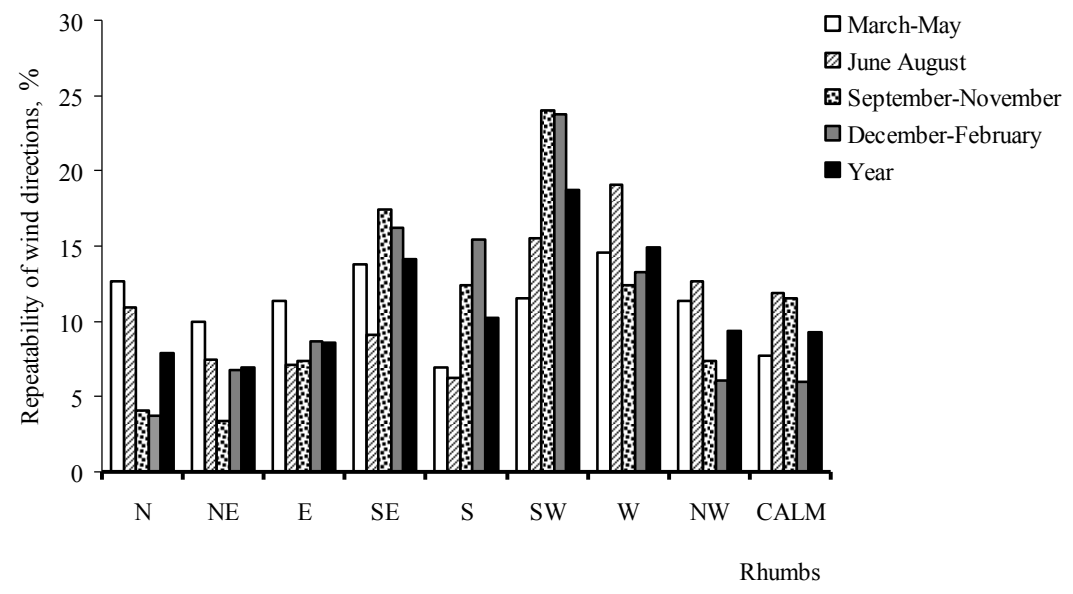

Fig. 1. Repeatability of wind directions by eight rhumbs over the water surface of the work area (according to data for the Kaliningrad point).

The wind data for 2004-2009 was also used for the Baltic Sea. They were obtained with the help of an automatic hydro-meteorological station (AHMS) MLCP D-6 at an altitude of $27 \mathrm{~m}$ above sea level (Oil and the environment...., 2012). The standard height of the installation of instruments is $10 \mathrm{~m}$ above sea level. Therefore during meteorological observations behind the wind, the recalculation was carried out on the basis of the dependence of the wind speed on the altitude according to Helman's formula (Oil and the environment...., 2012): 


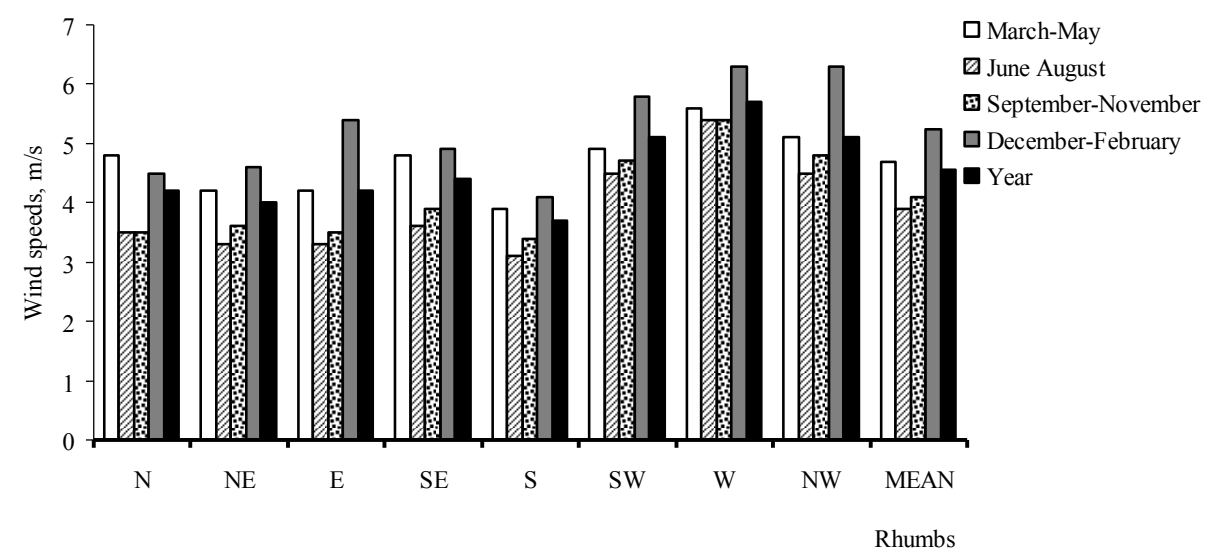

Fig. 2. Wind speeds over eight rhumbs over the water surface of the work area (according to data of the Kaliningrad point).

$$
V_{h}=V_{10}(0.233+0.656 \lg (h+4.75)) \text {, }
$$

where $V_{h}$ - wind speed at height $h ; V_{10}$ - wind speed at an altitude of $10 \mathrm{~m}$ above sea level. The results of the calculations are given in Table. 1, and graphically calculated wind speeds and directions with standard deviations averaged for each month of the year for 2004-2009 are shown in fig. 3 and 4.

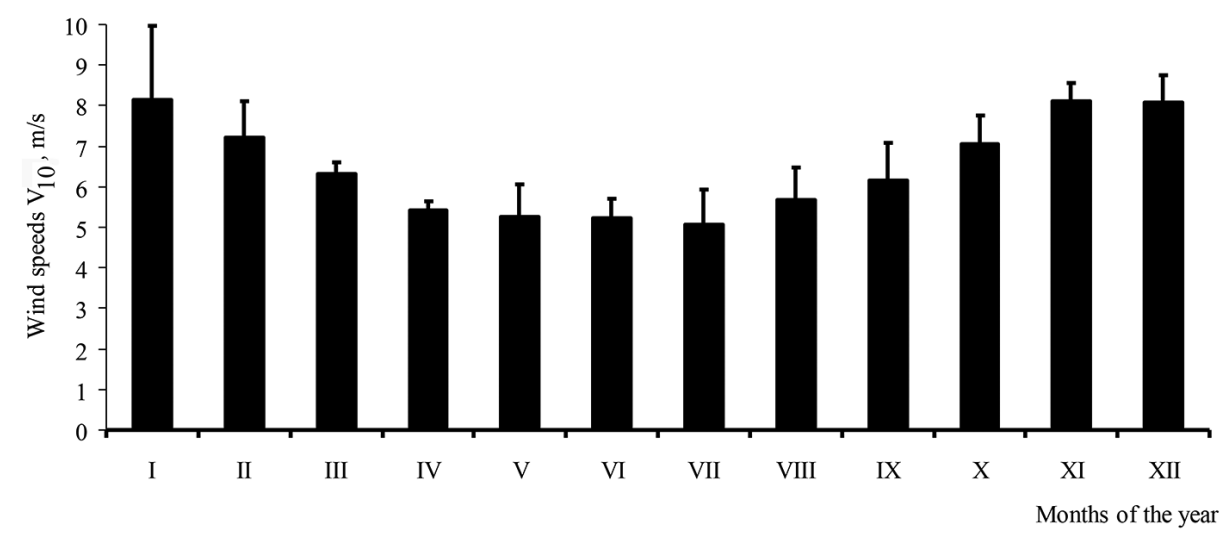

Fig. 3. Wind speeds in the work area at a height of $10 \mathrm{~m}$ above the water surface (according to data of the AHMS, located on the MLCPD-6).

Thus, from June to October, over the work area, the average annual wind speed changes within 5.1-7.0 (mean $5.8 \pm 1.0$ ) $\mathrm{m} / \mathrm{sec}$, and the average annual wind directions vary from 207 to $275^{\circ}$ (average $240 \pm 71^{\circ}$ ). At a height of $10 \mathrm{~m}$ directly above the water surface, the wind speed is about $1.5-2.0 \mathrm{~m} / \mathrm{sec}$ higher compared to the wind speeds measured above the land.

It should be taken into account that in the period of work the probability of a wind of western rhumb is $45-60 \%$, and of northern rhumb - up to $10 \%$. In early autumn, the probability of western winds decreases to $30-40 \%$; the frequency of south-east and south winds is also high $(\sim 30 \%)$. By October, the probability of the south-eastern and especially southern wind increases, and the south-west wind drops to 15-30\% (Oil and the environment.., 2012). 
Table 1. Recalculation of wind speed and directions according to Helman's formula, using the data of measurements for 2004-2009 performed on MLCP D-6

\begin{tabular}{|c|c|c|c|c|c|c|c|c|c|c|c|c|c|c|}
\hline \multirow[t]{2}{*}{ Year } & \multirow{2}{*}{$\begin{array}{l}\text { Para- } \\
\text { meter }\end{array}$} & \multicolumn{12}{|c|}{ Month } & \multirow{2}{*}{$\begin{array}{l}\text { For } \\
\text { year }\end{array}$} \\
\hline & & I & II & III & IV & V & VI & VII & VIII & IX & X & XI & XII & \\
\hline \multirow{3}{*}{2004} & $D^{\circ}$ & 120 & 345 & 275 & 120 & 285 & 270 & 260 & 200 & 285 & 195 & 285 & 270 & 245 \\
\hline & $\begin{array}{l}277^{2} \\
\mathrm{~m} / \mathrm{sec}\end{array}$ & 7.5 & 7.5 & 7.6 & 6.7 & 7.9 & 6.4 & 6.8 & 6.5 & 9.5 & 8.6 & 9.9 & 9.1 & 7.8 \\
\hline & $\begin{array}{l}10 \\
\mathrm{~m} / \mathrm{sec}\end{array}$ & 6.2 & 6.2 & 6.2 & 5.5 & 6.5 & 5.3 & 5.6 & 5.3 & 7.8 & 7.1 & 8.1 & 7.5 & 6.4 \\
\hline \multirow{3}{*}{2005} & $D^{\circ}$ & 250 & 135 & 20 & 95 & 215 & 270 & 215 & 220 & 190 & 185 & 200 & 165 & 180 \\
\hline & $\begin{array}{l}27 \\
\mathrm{~m} / \mathrm{sec}\end{array}$ & 11.2 & 9.2 & 7.8 & 6.5 & 5.9 & 6.7 & 5.1 & 7.7 & 6.8 & 8.8 & 9.9 & 10.4 & 8.0 \\
\hline & $\begin{array}{l}V_{10} \\
\mathrm{~m} / \mathrm{sec}\end{array}$ & 9.2 & 7.6 & 6.4 & 5.3 & 4.8 & 5.5 & 4.2 & 6.3 & 5.6 & 7.2 & 8.1 & 8.5 & 6.6 \\
\hline \multirow{3}{*}{2006} & $D^{\circ}$ & 160 & 105 & 175 & 190 & 240 & 310 & 10 & 335 & 220 & 225 & 230 & 250 & 205 \\
\hline & $\begin{array}{l}27 \\
\mathrm{~m} / \mathrm{sec}\end{array}$ & 7.5 & 7.5 & 7.1 & 6.5 & 7.2 & 5.3 & 4.9 & 5.9 & 6.9 & 9.0 & 9.5 & 10.7 & 7.3 \\
\hline & $\begin{array}{l}V_{10}, \\
\mathrm{~m} / \mathrm{sec}\end{array}$ & 6.2 & 6.2 & 5.8 & 5.3 & 5.9 & 4.4 & 4.0 & 4.8 & 5.7 & 7.4 & 7.8 & 8.8 & 6.0 \\
\hline \multirow{3}{*}{2007} & $D^{\circ}$ & 255 & 120 & 200 & 295 & 215 & 235 & 255 & 265 & 245 & 330 & 250 & 210 & 240 \\
\hline & $\begin{array}{l}27 \\
\mathrm{~m} / \mathrm{sec}\end{array}$ & 12.1 & 9.8 & 7.9 & 6.9 & 5.8 & 6.7 & 7.2 & 6.9 & 8.1 & 8.0 & 9.4 & 9.2 & 8.2 \\
\hline & $\begin{array}{l}V_{10}, \\
\mathrm{~m} / \mathrm{sec}\end{array}$ & 9.9 & 8.0 & 6.5 & 5.7 & 4.8 & 5.5 & 5.9 & 5.7 & 6.6 & 6.6 & 7.7 & 7.6 & 6.7 \\
\hline \multirow{3}{*}{2008} & $D^{\circ}$ & 195 & 250 & 230 & 55 & 10 & 265 & 320 & 250 & 55 & 230 & 225 & 180 & 190 \\
\hline & $\begin{array}{l}V_{27}, \\
\mathrm{~m} / \mathrm{sec}\end{array}$ & 12.3 & 10.0 & 7.7 & 6.2 & 5.4 & 6.1 & 5.9 & 8.4 & 7.1 & 9.8 & 10.9 & 9.0 & 8.2 \\
\hline & $\begin{array}{l}V_{10} \\
\mathrm{~m} / \mathrm{sec}\end{array}$ & 10.1 & 8.2 & 6.3 & 5.1 & 4.4 & 5.0 & 4.8 & 6.9 & 5.8 & 8.0 & 8.9 & 7.4 & 6.8 \\
\hline \multirow{3}{*}{2009} & $D^{\circ}$ & 180 & 240 & 125 & 80 & 75 & 295 & 335 & 245 & 245 & 250 & 280 & 185 & 210 \\
\hline & $\begin{array}{l}V_{27} \\
\mathrm{~m} / \mathrm{sec}\end{array}$ & 9.0 & 8.6 & 8.1 & 6.8 & 6.3 & 6.9 & 7.2 & 6.1 & 6.5 & 7.3 & 9.7 & 10.6 & 7.8 \\
\hline & $\begin{array}{l}V_{10}, \\
\mathrm{~m} / \mathrm{sec}\end{array}$ & 7.4 & 7.1 & 6.6 & 5.6 & 5.2 & 5.7 & 5.9 & 5.0 & 5.3 & 6.0 & 8.0 & 8.7 & 6.4 \\
\hline
\end{tabular}

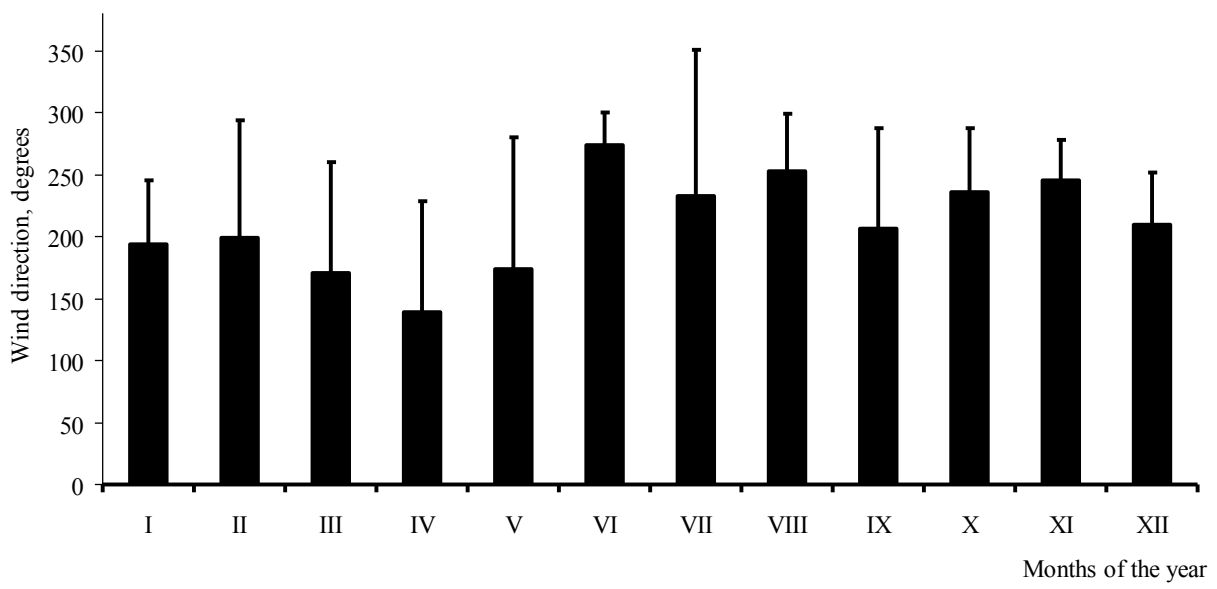

Fig. 4. Wind directions over the water surface of the work area (according to data for AHMS, located on MLCPD-6). 
Currents. The main factors in the formation of intensity, direction and vertical structure of currents in the MA district are wind influence on the sea surface, seasonal variability of hydro-meteorological and hydrological conditions and inertial effects of Earth's rotation (Oil and the environment...., 2012). The current velocity in the district of MLCP D-6 during the observation period did not exceed $20 \mathrm{~cm} / \mathrm{sec}$, and its average at the surface and in the bottom layer was $\sim 10-12$ and $6-10 \mathrm{~cm} / \mathrm{sec}$, respectively.

Under certain conditions in summer, a layered structure of currents can be established due to thermocline development and space-temporal dynamics of inertial oscillations (Oil and the environment..., 2012). The passage of an intense wind disturbance (cyclone) can cause a local, uniform deep circulation. Such currents are characteristic for the autumn period, they vary depending on the variability of the wind.

Temperature $\boldsymbol{T}_{w}$ and salinity $\boldsymbol{S}_{w}$ of sea waters. During 2003-2008 on the selected sections of the Baltic Sea, 20 surveys of hydrological observations of $T_{W}$ and $S_{W}$ were performed (Oil and the environment...., 2012). For the MA region, the average summer (in July) $T_{W}$ on the sea surface was $18.2^{\circ} \mathrm{C}$, and the average annual $-10.4{ }^{\circ} \mathrm{C}$. In summer, $S_{W}$ is minimal (7.05\%) with an average annual value of $7.17 \%$ (Table 2).

In July and October-November, the average $T_{W}$ for the $0-20 \mathrm{~m}$ layer on the UCS area was 16.0 and $12.3{ }^{\circ} \mathrm{C}$ respectively, and for the $0-30 \mathrm{~m}$ layer in the MA region -14.8 and $12.7^{\circ} \mathrm{C}$ in the same months. The average $S_{W}$ for the $0-20 \mathrm{~m}$ layer for the UCS area was 7.03 and $7.01 \%$ in July and October-November respectively, and for the 0-30 m layer $S_{W}$ for the MA region was $7.2 \%$ for the same periods.

Table 2. Season-average values of $T_{w} / S_{w}\left({ }^{\circ} \mathrm{C} / \%\right.$ oo $)$ for 2003-2008 (Oil and the environment..., 2012) ( $\sigma$ - standard deviations values of $T_{w}$ and $S_{w}$; MA - monitoring area, UCS - underwater coastal slope)

\begin{tabular}{|c|l|l|l|l|l|l|l|l|}
\hline \multirow{2}{*}{$\begin{array}{c}\text { Depth, } \\
\mathrm{m}\end{array}$} & \multicolumn{7}{|c|}{ July } \\
\cline { 2 - 9 } & \multicolumn{7}{|c|}{ Mean for $2003-2008$} \\
\cline { 2 - 9 } & UCS & $\sigma$ & $\sigma$ & UCS & $\sigma$ & MA & $\sigma$ \\
\hline 0 & $18.57 / 6.91$ & $2.18 / 0.16$ & $18.20 / 7.05$ & $2.59 / 0.20$ & $12.19 / 6.89$ & $3.10 / 0.72$ & $12.72 / 7.12$ & $2.66 / 0.45$ \\
5 & $17.90 / 6.93$ & $1.97 / 0.17$ & $17.72 / 7.05$ & $2.34 / 0.20$ & $12.22 / 6.99$ & $3.08 / 0.34$ & $12.74 / 7.16$ & $2.65 / 0.24$ \\
10 & $15.99 / 6.99$ & $3.00 / 0.22$ & $16.36 / 7.10$ & $2.27 / 0.19$ & $12.09 / 7.00$ & $3.14 / 0.35$ & $12.70 / 7.16$ & $2.68 / 0.24$ \\
15 & $14.20 / 7.12$ & $2.65 / 0.18$ & $14.55 / 7.20$ & $1.88 / 0.12$ & $12.30 / 7.08$ & $3.33 / 0.16$ & $12.89 / 7,22$ & $2.54 / 0.14$ \\
20 & $13.60 / 7.20$ & $2.70 / 0.09$ & $13.14 / 7.25$ & $2.16 / 0.10$ & $12.57 / 7.09$ & $3.57 / 0.17$ & $12.94 / 7.23$ & $2.51 / 0.13$ \\
30 & - & - & $8.90 / 7.34$ & $3.47 / 0.10$ & - & - & $12.44 / 7.27$ & $2.76 / 0.13$ \\
40 & - & - & $5.13 / 7,43$ & $2.42 / 0.11$ & - & - & $8.93 / 8.18$ & $3.85 / 3.91$ \\
50 & - & - & $3.99 / 7.51$ & $1.37 / 0.14$ & - & - & $6.45 / 7.62$ & $3.83 / 0.40$ \\
60 & - & - & $3.37 / 7.82$ & $0.96 / 0.74$ & - & - & $4.52 / 8.39$ & $1.56 / 0.96$ \\
70 & - & $4.31 / 8.58$ & $0.65 / 0.60$ & - & - & $5.17 / 9.87$ & $0.62 / 0.84$ \\
80 & - & - & $5.34 / 10.31$ & $0.94 / 1.11$ & - & - & $5.67 / 11.13$ & $0.58 / 0.68$ \\
90 & - & - & $6.39 / 11.74$ & $0.73 / 0.68$ & - & - & $5.90 / 11.49$ & $0.54 / 0.53$ \\
100 & - & - & $6.71 / 12.43$ & $1.13 / 0.52$ & - & - & $6.72 / 12.21$ & $0.80 / 1.00$ \\
110 & - & - & - & & - & $6.69 / 12.41$ & $0.73 / 0.92$ \\
\hline
\end{tabular}




\subsection{Characteristics of sand material in bottom sediments of the work area}

The initial sand material at the site of work includes sand particles of different sizes (from 0.2 to $2 \mathrm{~mm}$ or from small to coarse grains). The granulometric composition of the sand intended for washing up deposits is presented in Table. 3.

The value of the resistance coefficient $C_{D}$ for the two-dimensional version of the hydrodynamic module is calculated using the ratio (2.18) (Podgornyi, Leonov, 2017):

$$
C_{D}=0.16\left(1+\ln \left(\frac{Z_{0}}{Z_{w}}\right)\right)^{-2},
$$

where $Z_{0}$ is some average scale of the height of the roughness protrusions on the bottom, determined by the equation $Z_{0}=D_{50} / 12\left(D_{50}\right.$ is the mean-weighted size of particle dependent on the percentage contribution of particles with different types and sizes present in the sediment layer in the water body) (Stanev et al., 2009); $Z_{W}$ is the water depth for the place of study.

Data on the granulometric composition of the sand allow us to determine the limits of the change in the scale of the roughness protrusions $Z_{0}$ for the area under which the calculations are performed. On the basis of Table 3, we will calculate the values of $D_{50}$ for the upper and lower boundaries of the size intervals:

- for the upper boundary of the considered intervals -

$10 \times 0.003+2 \times 0.033+1 \times 0.053+0.5 \times 0.683+0.25 \times 0.212+0.1 \times 0.016=0.545(\mathrm{~mm}) ;$

- for the lower boundary of the considered intervals -

$2 \times 0.003+1 \times 0.033+0.5 \times 0.053+0.25 \times 0.683+0.1 \times 0.212+0.05 \times 0.016=0.258(\mathrm{~mm})$.

Thus, the values of $D_{50}$ for the upper and lower boundaries of the size intervals are 0.545 and $0.258 \mathrm{~mm}$, respectively, and the average scales $Z_{0}$ of the height of the roughness protrusions on them are $Z_{0}=0.045 \mathrm{~mm}$ (or $4.5 \times 10^{-5} \mathrm{~m}$ ) and $0.022 \mathrm{~mm}$ (or $2.2 \times 10^{-5}$ $\mathrm{m}$ ), and the average scale $Z_{0}=0.034 \mathrm{~mm}$ (or $3.4 \times 10^{-5} \mathrm{~m}$ ).

According to the data on the granulometric composition of the transported sediments (Table 3), we also calculate the effective rate of sedimentation using the dependence (Methodological guidelines...., 2003):

$$
W_{s}=\frac{\sum_{n=1}^{M}\left(W_{s}\right)_{n} P_{n}}{P},
$$

where $M$ is the number of isolated fractions of ground particles $\leq 0.1 \mathrm{~mm}$ in size; $\left(W_{s}\right)_{n}$ - the hydraulic size of the individual $n$-th fractions of particles (determined from Table 4), $\mathrm{cm} / \mathrm{sec} ; P_{n}$ - the weight content in the soil of individual $n$-th fractions of particles of $\leq 0.1 \mathrm{~mm}$ in size, in fractions of a unit; $P$ - weight total content in the soil of particles of $\leq 0.1 \mathrm{~mm}$ in size, in fractions of a unit.

Now we estimate for $T_{W}=15^{\circ} \mathrm{C}$ the average effective sedimentation rate based on the data of Table 3 and 4 , and this rate will be

$$
W_{s}=(0.1864 \times 0.016+0.679 \times 0.212) /(0.016+0.212)=0.64 \mathrm{sm} / \mathrm{sec}(\text { or } 0.0064 \mathrm{~m} / \mathrm{sec}) \text {. }
$$


Table 3. The granulometric composition of sand, presumed to be deposited (*medium-grained sand)

\begin{tabular}{|c|c|c|c|c|c|c|c|c|}
\hline Type of & \multicolumn{7}{|c|}{ Fraction, mm } \\
\hline sediment & $100-10$ & $10-2$ & $2-1$ & $1-0.5$ & $0.5-0.25^{*}$ & $0.25-0.1$ & $0.1-0.05$ & Amount \\
\hline & \multicolumn{8}{|c|}{ Content, \% } \\
\hline ПС & 0.0 & 0.3 & 3.3 & 5.3 & 68.3 & 21.2 & 1.6 & 100.0 \\
\hline
\end{tabular}

Table 4. Hydraulic size of the slurry $W_{s}$, sm/sec (Methodological guidelines...., 2003)

\begin{tabular}{|c|c|c|c|c|c|}
\hline \multirow{2}{*}{$\begin{array}{c}\text { Diameter of } \\
\text { particles, } \mathrm{mm}\end{array}$} & \multicolumn{5}{|c|}{$T_{w}{ }^{\circ} \mathrm{C}$} \\
\cline { 2 - 6 } & 5 & 10 & 15 & 20 & 25 \\
\hline 0.05 & 0.1426 & 0.1640 & 0.1864 & 0.2097 & 0.2340 \\
\hline 0.1 & 0.530 & 0.604 & 0.679 & 0.755 & 0.833 \\
\hline
\end{tabular}

It is assumed that for the simple case, the flocculation process will not be taken into account in calculations.

\subsection{Technological data defining the conditions for the performance of work}

We estimate for the work period (from June to October with total duration 180 days) the values of the parameters required in the model for calculations.

It is assumed that for work on bypassing, the self-hauling bilge pump "BRABO" will be used. The maximum capacity of its holds is $11650 \mathrm{~m}^{3}$ (at the upper overflow level). The cargo capacity of the hold is 18397 tons. The average speed of the movement is $10 \mathrm{knots}(18 \mathrm{~km} / \mathrm{h})$ with an average distance $18 \mathrm{~km}$ to the working place. The time spent per one trip is 10 hours ( 6 hours for dredging, 2 hours for moving from the place of work to the place of unloading and back and 2 hours for unloading the cargo hold through the pipelines system).

To move 2.1 million $\mathrm{m}^{3}$ of sand material, 180 trips should be make (on 10 hours for each trip), and total time for entire work on bypassing is 1800 hours. The speed of the vessel during the deepening is $2 \mathrm{~km} / \mathrm{h}$. Loading of soil into the bilge will be carried out with overflow (estimated coefficient of soil loss at dredging of 0.3 for medium-grained sands).

The projected volumetric weight of the soil is $1.52 \mathrm{t} / \mathrm{m}^{3}$. The total capacity of a single water-pumping pump for dredging is $2100 \mathrm{~m}^{3} / \mathrm{h}$, and when working with two pumps $-4200 \mathrm{~m}^{3} / \mathrm{h}$.

At the dredging by self-hauling dredgers with hydrodusters, the most extensive turbidity zones are formed at the bottom when the rippers are working before sucking. The overflowing from the hold of the dredge may be registered when it is filled, and it is possible to form turbidity zones on the water surface. When dredging in soils with an 
effective sedimentation rate of a suspension of $W_{\mathrm{s}} \leq 0.2 \mathrm{~cm} / \mathrm{sec}$, a cloud of turbidity can be propagated (rising) from the bottom to the middle of the water depth (Methodological guidelines...., 2003).

Thus, taking into account the possible overflow from the hold of the dredge while filling it, the expected cloud of turbidity will cover the entire water column of the considered water area in the dredging region.

\subsection{Calculation of ground losses for the formation of suspensions during dredging operations}

The main data in determining the characteristics of the turbidity spot at the dredging are the effective sedimentation rate of the $\mathrm{SM}, W_{\mathrm{s}}$, and the loss $q$ of the soil consisting into the suspended form. The calculation $W_{S}$ was performed as shown above and the result is $0.64 \mathrm{sm} / \mathrm{sec}$ (or $0.0064 \mathrm{~m} / \mathrm{sec}$ ). Losses $q$ in $\mathrm{t} / \mathrm{sec}$ are calculated by the equation (Methodological guidelines...., 2003):

$$
q=\left(P k Q \gamma_{S} \frac{\gamma-\gamma_{W}}{\gamma_{S}-\gamma_{W}}\right) / 3600,
$$

where $P$ - the weighted total content in the soil of particles of $\leq 0.1 \mathrm{~mm}$ in size, in fractions of the unit forming the zone of increased turbidity (determined from the data on the granulometric composition of the soil dredging); $k$-coefficient of soil transformation into the suspension during the operation of technical means (spillage), in fractions of a unit; $Q$ - the productivity of the technical means on the ground, $\mathrm{m}^{3} / \mathrm{h}$ (determined by the technological characteristics of the dredge); $\gamma$ - the projected volumetric weight of the soil in a state of natural construction, $\mathrm{t} / \mathrm{m}^{3} ; \gamma_{W}$ - the volume weight of water, $\mathrm{t} / \mathrm{m}^{3} ; \gamma_{S}$ - the specific gravity of ground particles, $\mathrm{t} / \mathrm{m}^{3}$.

The value $P$, according to the data on the granulometric composition of the dredging is $0.016+0.212=0.228$. In the absence of data to determine the coefficient $k$ at the operating technical means, we assume tentatively that $k=0.05(5 \%)$ (Methodological guidelines...., 2003). The total capacity $Q$ of technical facilities (two pumps for loosening) on the ground is $4200 \mathrm{~m}^{3} / \mathrm{h}$. The projected volumetric weight $\gamma$ of the soil is assumed equal to $1.52 \mathrm{t} / \mathrm{m}^{3}$. The volume weight $\gamma_{W}$ of water $=1.0 \mathrm{t} / \mathrm{m}^{3}$. The coefficient of soil porosity is 0.67 (according to laboratory tests of their physico-mechanical properties). Then the specific gravity of soil particles is $\gamma=\gamma / 0.67=1.52 / 0.67=2.27 \mathrm{t} / \mathrm{m}^{3}$.

Thus, the loss $g$ of soil particles passing into the slurry (when dredging with two hydraulic loosening pumps) and forming of turbidity zone (taking into account the physical and mechanical properties of the developed soil) will amount to

$$
q=\left(0.228 \cdot 0.05 \cdot 4200 \cdot 2.27 \cdot \frac{1.52-1.0}{2.27-1.0}\right) / 3600=0.01236167(t / \mathrm{sec}) .
$$

Taking into account that $1 t=10^{6} \mathrm{~g}$, we obtain that $q$ will be $12361.67 \mathrm{~g} / \mathrm{sec}$. 


\subsection{Calculation of soil losses for the formation of suspensions when loading soil in the hold of the dredger with overflow}

When the soil is loaded into the hold of the dredger with overflow, the most extensive zones of the suspension are formed on the water surface with a gradual lowering of suspensions content into the depths. The main initial data for determining the characteristics of the turbidity spot during overfilling are the effective sedimentation rate $W_{S}$ and the mass $G$ of the soil, which passes into a suspended state. The value $W_{S}$ estimated above is $0.64 \mathrm{sm} / \mathrm{sec}$ (or $0.0064 \mathrm{~m} / \mathrm{sec}$ ). Soil mass $G$ in t is calculated by the equation (Methodological guidelines...., 2003):

$$
G=P k_{1} V \gamma_{S} \frac{\gamma-\gamma_{W}}{\gamma_{S}-\gamma_{W}}
$$

where $P$ - the weighted total content in the soil of particles of $\leq 0.1 \mathrm{~mm}$ in size, in fractions of unit, forming the zone of increased turbidity (determined from the data on the granulometric composition of the bottom of the dredging); $k_{1}$ - coefficient of ground transformation into a weighed state at overflow during operation of technical means, in fractions of a unit; $V$ - loading rate of the ship's hold in terms of volume in the state of natural addition, $\mathrm{m}^{3}$ - is determined by the technological characteristics of the dredge; $\gamma-$ projected volumetric weight of soil in a state of natural addition, $\mathrm{t} / \mathrm{m}^{3} ; \gamma_{W}$-volumetric weight of water, $\mathrm{t} / \mathrm{m}^{3} ; \gamma_{S}$ - specific gravity of soil particles, $\mathrm{t} / \mathrm{m}^{3}$.

Coefficient $k_{1}=0.3$. The maximum capacity $V$ of the hold at the upper level of overflow is $11650 \mathrm{~m}^{3}$. Thus, the total mass of soil particles $G$ that have passed into the suspended state as a result of overflow and forming a turbidity zone for a single time of dredging $(6 \mathrm{~h})$, in accordance with equation (3.4) is estimated as

$$
G=0.228 \cdot 0.3 \cdot 11650 \cdot 2.27 \cdot \frac{1.52-1.0}{2.27-1.0}=740.640586 \mathrm{t},
$$

which is approximately $4 \%$ of the load capacity of the dredge hold (equal to 18397 tons). Knowing the value $G$, we can now estimate the amount of soil particles $G^{*}$ that pass into the slurry during dredging as a result of overflow in one second:

$$
G^{*}=G /(6 \cdot 3600)=740.640586 /(6 \cdot 3600)=0.03428892 \mathrm{t} / \mathrm{sec} .
$$

Taking into account that $1 \mathrm{t}=10^{6} \mathrm{~g}$, we find that the loss $G^{*}$ is $3428892 \mathrm{~g} / \mathrm{sec}$.

\subsection{An estimate of the average vertical concentration of the total SM concentration in water during dredging and loading of soil into the hold of the dredger with overflow}

According to the above calculations, at the dredging and loading of soil into the hold of the dredge with overflow, the input of SM, equal to $12361.67+34288.92=46650.59 \mathrm{~g}$, 
will delive every second into the water column. For 6 hours of daily operation, the area of the bottom damage will be equal to $\frac{1.82 \times 10^{6}}{180}=10111.1 \mathrm{~m}^{2}$, and $46650.59 \times 3600 \times 6=$ $1007652744 \mathrm{~g}$ ( or $\approx 1007.65$ tons) will be delivered in the water column. At an average depth of $27.5 \mathrm{~m}$ of the water area of the work region, we obtain that the average vertical concentration of the total concentration of SM entering the water every second during dredging and loading of soil into the hold of the dredger with overflow will be $46650.59 \mathrm{~g} /\left(1 \mathrm{~m}^{2} \times 27.5 \mathrm{~m}\right)=1696.39 \mathrm{~g} / \mathrm{m}^{3}$ (or $\left.1696.39 \mathrm{mg} / \mathrm{L}\right)$.

\subsection{Parameters of the grid area}

For calculations, the grid area should be determined for the water area within which the soil sampling will be carried out. We propose a grid of an area with 50 nodes along the horizontal axis $O X$ and 31 - along the vertical axis $O Y$ (or with a total number of nodes $50 \times 31)$. Spatial steps along the grid axes will be denoted $(\Delta s)_{x},(\Delta s)_{y}$ respectively with respect to the spatial coordinates $x$ and $y$. They are assumed to be constant and amount to $250 \mathrm{~m}$. Thus, the dimensions of the calculated area are $49 \times 250 \mathrm{~m}=12250 \mathrm{~m}$ along the $O X$ axis and $30 \times 250 \mathrm{~m}=7500 \mathrm{~m}$ along the $O Y$ axis. They outline a larger area in comparison with the actual area of the work area for the dredging.

All the boundaries of the grid area are open. The values of the environmental parameters (current velocities, sea level changes) at open borders are not known from observations, therefore zero values of the free surface level will be given for calculations at these boundaries. The sizes of the calculated area are quite large in comparison with the dredging area, and it itself is located at a sufficient distance from the boundaries, so the uncertainty of the given boundary conditions in the calculation of the currents will not lead to significant distortions in the design velocities and directions of the currents.

The maximum depth $H_{\max }$ within the grid area covering the water area of the work site is $36.3 \mathrm{~m}$. The time step $\tau$ depends on the steps $(\Delta s)_{x},(\Delta s)_{y}$ of the grid over on the spatial coordinates. At the choosing $\tau$, it is necessary to ensure the codition that the stability criterion of Courant-Friedrichs-Levy calculations (CFL) is satisfied, according to which the inequality should be

$$
\tau<\frac{(\Delta s)_{x, y}^{\max }}{\sqrt{g H_{\max }}},
$$

where $(\Delta s)_{x, y}^{\max }$ is the largest step of the grid with respect to the spatial coordinates (in this case $\left.(\Delta s)_{x, y}^{\max }=(\Delta s)_{x}=(\Delta s)_{y}=250 \mathrm{~m}\right)$.

After substituting in the equation (3.5) all the required numerical values of the parameters, we find that for numerical integration of the system of hydrodynamic equations the time step must be $<\frac{250}{\sqrt{9.81 \cdot 36.3}}=13.25 \mathrm{sec}$. For the convenience of calculations, we assume that the time step $\tau$ will be 10 seconds. 
We will use the same time step at the numerical integration of the system equations of evolutional advection and turbulent diffusion in the calculation of the transport of SM for the region of dredging.

We use the speed of the vessel during the deepening equal to $2 \mathrm{~km} / \mathrm{h}$. Suppose that the input of SM into the marine environment (as a result of dredging and overflow) will occur "pointwise" at the corresponding nodes of the calculation grid. Accordingly, "moving" the vessel to the next node at the selected step of the calculation grid $250 \mathrm{~m}$ and a time step of $10 \mathrm{sec}$ will occur every 45 steps in time according to the proposed scheme of the vessel "moving" (Fig. 5).

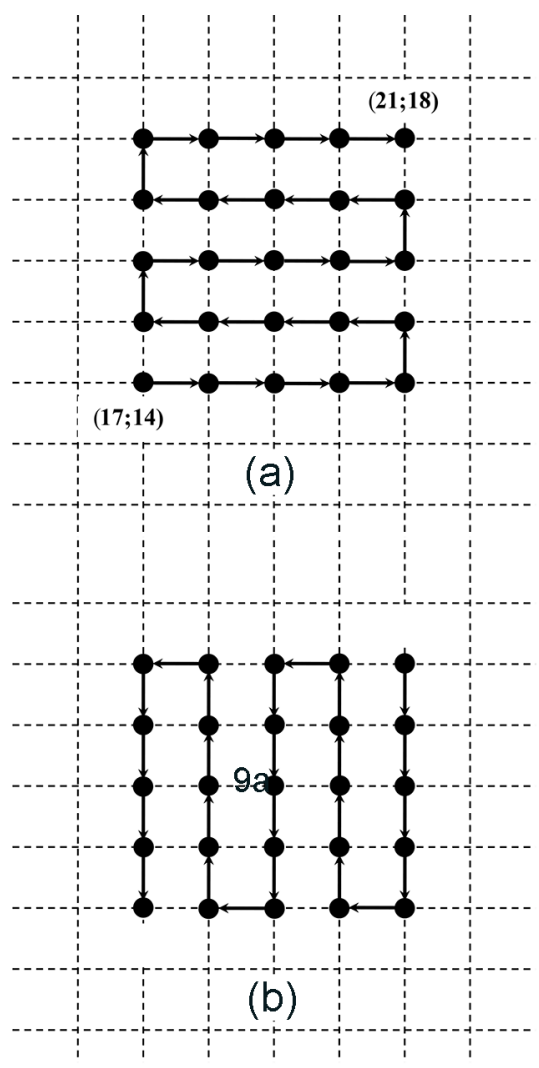

Fig. 5. Scheme of vessel «moving» within the calculation field in the dredging area: (a) - moving from the node with grid coordinates $(17 ; 14)$ to the node with grid coordinates $(21 ; 18)$; (b) is a reverse movement from a node with grid coordinates $(21 ; 18)$ to a node with grid coordinates $(17 ; 14)$.

The specified start time for the beginning of work is 9 hours and for its end -15 hours.

\subsection{Estimation of the coefficient of horizontal turbulent exchange $\left(A_{\eta}\right)_{n}$}

To estimate the value of horizontal turbulent exchange coefficient $\left(A_{\eta}\right)_{n}$ for the size fraction $n$, we use equation (2.39) (Afanasyev, Ryanzhin, 1986):

$$
\left(A_{\eta}\right)_{n}=\alpha\left((\Delta s)_{x}(\Delta s)_{y}\right) \sqrt{2\left(\frac{\partial U}{\partial x}\right)^{2}+\left(\frac{\partial U}{\partial y}+\frac{\partial V}{\partial x}\right)^{2}+2\left(\frac{\partial V}{\partial y}\right)^{2}}
$$

where $(\Delta s)_{x},(\Delta s)_{y}$ - grid steps for spatial coordinates $x$ and $y$ respectively; coefficient $\alpha=0.1$. In calculating the spatial derivatives $\partial U / \partial x, \partial U / \partial y, \partial V / \partial x, \partial V / \partial y$, a central-difference approximation was used. 


\subsection{Estimation of the critical values of the tangential stress at the bottom of the water body determining the onset of SM sedimentation and the bottom sediment resuspension}

The SM sedimentation and the resuspension of bottom sediment will occur only when the value of the tangential stress at the bottom of the water body $\tau_{\text {bottom }}$ will be either $<\tau_{C_{n}}^{\text {crit_sed }}$ or $\tau_{C_{n}}^{\text {crit_resusp }}>$ respectively (Podgorny, Leonov, 2017). Critical values $\tau_{C_{n}}^{\text {crit_sed }}$

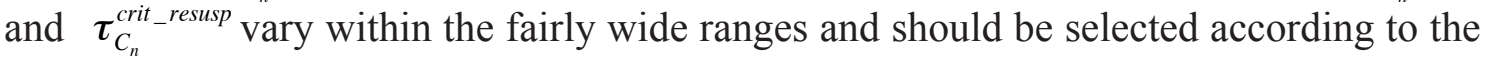
results of model calibration used for the study of the sediment transport in lakes, coastal zones of the seas and sea bays. Existing studies and modeling experience show that the values $\tau_{C_{n}}^{\text {crit_sed }}$ vary in the range $0.0-0.18 \mathrm{~N} / \mathrm{m}^{2}$ ( $N$ is a Newton as force unit), and the values $\tau_{C_{n}}^{\text {crit resusp }}$ - in range from 0.009 to $0.25 \mathrm{~N} / \mathrm{m}^{2}$ (Chao et al., 2008; Hamilton, Mitchell, 1996; Lou et al., 2000; Mehta, Partheniades, 1975; Ziegler, Nisbet, 1995).

We estimate the approximate value $\tau_{\text {bottom }}^{\text {curr }}$ by formula (2.17) (Podgorny, Leonov, 2017). Taking into account the bathymetry of the work area, it can be concluded that the contribution of the term $\tau_{\text {bottom }}^{\text {curr }}$ at the calculation will be decisive. With an average scale height $Z_{0}$ of ridges of roughness equal to $3.4 \times 10^{-5} \mathrm{~m}$, an average depth of the water area of the work area $-27.5 \mathrm{~m}$, a water density of $1000 \mathrm{~kg} / \mathrm{m}^{3}$, and a flow velocity of $0.1 \mathrm{~m} / \mathrm{sec}$, we obtain

$$
\begin{gathered}
C_{D}=0.16\left(1+\ln \left(\frac{Z_{0}}{Z_{w}}\right)\right)^{-2}=0.16\left(1+\ln \left(\frac{3.4 \cdot 10^{-5}}{27.5}\right)\right)^{-2}=0.0010073 ; \\
\tau_{\text {bottom }}^{\text {curr }}=\rho_{w} C_{D}\left(U^{\text {curr }}\right)^{2}=0.0010073 \cdot 10^{3} \cdot(0.1)^{2} \approx 0.01 \mathrm{~N} / \mathrm{m}^{2} .
\end{gathered}
$$

Based on the estimate obtained, we take as the first approximation that $\tau_{C_{n}}^{\text {crit_sed }}=0.01$, and $\tau_{C_{n}}^{\text {crit }{ }_{-} \text {resusp }}=0.02 \mathrm{~N} / \mathrm{m}^{2}$.

\section{Results of calculations on the sm-model}

With the help of the SM-model, we now calculate the main indicators by which we can judge the effect of dredging on the formation and presence of turbidity spots, the time spent in the water in the turbidity spot, and the thickness of the SM layer accumulated on the bottom surface during the settling of SM.

\subsection{The space-time structure of the turbidity fields}

Calculations on the SM-model were carried out to show every 30 minutes the position of the boundaries of the turbidity zones of water and the values of the square of such zones. Taking into account the average long-term data on wind (speed and direction) over the water area of the work site (Figures 3, and 4), calculations were made for wind speed $6 \mathrm{~m} / \mathrm{sec}$ and different directions - W $\left(270^{\circ}\right)$, NW $\left(225^{\circ}\right), \mathrm{S}\left(180^{\circ}\right)$, and NE $\left(45^{\circ}\right)$. 
Table 5. An example of calculating the parameters of turbidity zones and their areas at a wind speed of $6 \mathrm{~m} / \mathrm{sec}$ and its direction on the $\mathrm{W}\left(270^{\circ}\right)$

\begin{tabular}{|c|c|c|c|c|}
\hline $\begin{array}{l}\text { Tim (hour, } \\
\text { minute) }\end{array}$ & $\begin{array}{c}\text { Maximum } \\
\text { content of SM in } \\
\text { a zone of } \\
\text { turbidity, } \\
\mathrm{mg} / \mathrm{L}\end{array}$ & $\begin{array}{c}\text { Square of a zone } \\
\text { of turbidity, } \\
\mathrm{m}^{2}\end{array}$ & $\begin{array}{l}\text { Square of } \\
\text { a turbidity zone } \\
\text { with additional } \\
\text { concentration of } \\
\mathrm{SM} 50 \mathrm{mg} / \mathrm{L}, \mathrm{m}^{2}\end{array}$ & $\begin{array}{c}\text { Quota of } \\
\text { turbidity zone } \\
\text { square } \\
\text { with additional } \\
\text { concentration of } \\
\text { SM } 50 \mathrm{mg} / \mathrm{L} \\
\text { from } \\
\text { total square of a } \\
\text { turbidity zone, \% }\end{array}$ \\
\hline $9 \mathrm{~h} 00 \mathrm{~min}$ & 382.5 & 689741.5 & 468055.0 & 67.9 \\
\hline $9 \mathrm{~h} 30 \mathrm{~min}$ & 3597.0 & 1034550.6 & 993744.8 & 96.1 \\
\hline $10 \mathrm{~h} 00 \mathrm{~min}$ & 3377.3 & 949442.5 & 911410.1 & 96.0 \\
\hline $10 \mathrm{~h} 30 \mathrm{~min}$ & 3277.3 & 1047468.1 & 1003093.3 & 95.8 \\
\hline $11 \mathrm{~h} 00 \mathrm{~min}$ & 3810.8 & 892390.5 & 862566.0 & 96.7 \\
\hline $11 \mathrm{~h} 30 \mathrm{~min}$ & 3881.6 & 890871.0 & 861316.2 & 96.7 \\
\hline $12 \mathrm{~h} 00 \mathrm{~min}$ & 3000.4 & 1263049.5 & 1190047.5 & 94.2 \\
\hline $12 \mathrm{~h} 30 \mathrm{~min}$ & 4107.4 & 891160.0 & 859584.5 & 96.5 \\
\hline $13 \mathrm{~h} 00 \mathrm{~min}$ & 2980.5 & 1258648.9 & 1144712.5 & 91.0 \\
\hline $13 \mathrm{~h} 30 \mathrm{~min}$ & 3047.6 & 1224402.6 & 1165292.5 & 95.2 \\
\hline $14 \mathrm{~h} 00 \mathrm{~min}$ & 4353.1 & 883897.2 & 851620.4 & 96.4 \\
\hline $14 \mathrm{~h} 30 \mathrm{~min}$ & 4442.9 & 877430.2 & 843723.7 & 96.2 \\
\hline $15 \mathrm{~h} 00 \mathrm{~min}$ & 4427.4 & 880681.6 & 846016.5 & 96.1 \\
\hline
\end{tabular}

The areas of turbidity zones of water were estimated with the help of the Software package "Surfer" (version 8.01).

An example of appropriate calculations for wind speed $6 \mathrm{~m} / \mathrm{sec}$ and its direction to $\mathrm{W}\left(270^{\circ}\right)$ is given in Table 5, and graphically - in Fig. 6. The total area of water turbidity zone with an additional concentration of SM $(>50 \mathrm{mg} / \mathrm{L})$ and particle size $<0.14$ $\mathrm{mm}$ was calculated taking into account the specific positions of the boundaries of the turbidity zones and the possible intersection of the zones at one or another periods of time. The simulation data show that the maximum SM concentrations in the zones of additional turbidity at different times varied within $3.0-5.0 \mathrm{~g} / \mathrm{L}$. The area of the turbidity zone during the work varied from 0.69 to $1.32 \mathrm{~km}^{2}$. The share of the turbidity zone quare with an additional concentration of SM $(50 \mathrm{mg} / \mathrm{L})$ was $91-97 \%$ from the total area of the turbidity zone.

To calculate the volume of water with an additional concentration of SM, the total area of the turbidity zone was multiplied by the average depth $(27.5 \mathrm{~m})$ of the work area. The simulation data show that the volumes of turbidity zones during the work varied from 0.0190 to $0.0363 \mathrm{~km}^{3}$. Similar calculations at a wind speed of $6 \mathrm{~m} / \mathrm{sec}$ and its variable directions to $\mathrm{SE}\left(225^{\circ}\right), \mathrm{S}\left(180^{\circ}\right)$ and $\mathrm{SE}\left(45^{\circ}\right)$ showed that the differences in the final values of the calculated indicators are insignificant.

The total SM concentration entering to the water every second as a result of dredging and loading by soil into the hold of the dredger with overflow is sufficiently high $(1696.39 \mathrm{mg} / \mathrm{L})$. The formation of the turbidity spot, the duration of its existence with 


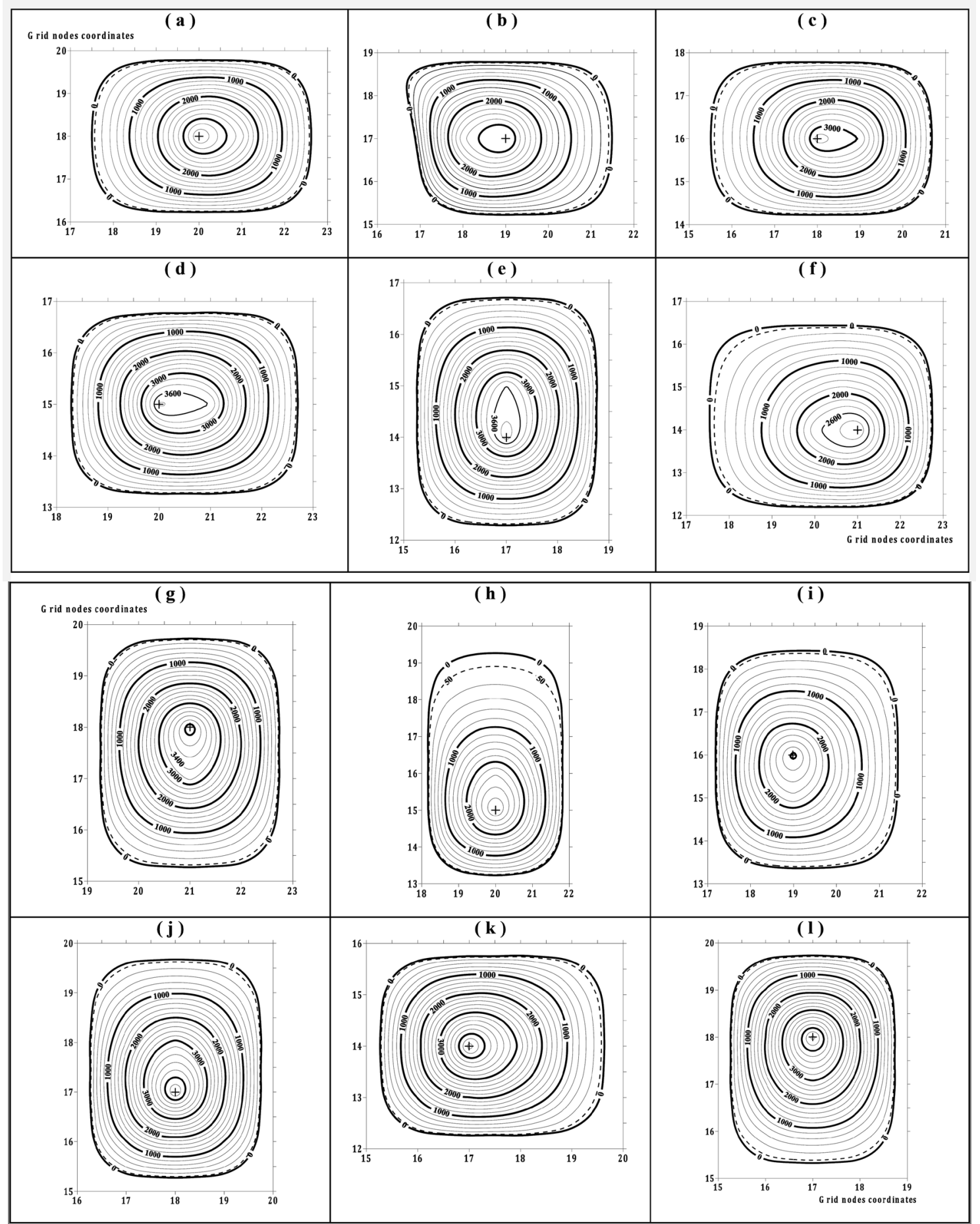

Fig. 6. Position of the spot in the additional turbidity zone and the value of the SM concentration $(\mathrm{mg} / \mathrm{L})$ at a wind speed of $6 \mathrm{~m} / \mathrm{sec}$, and the wind direction to $\mathrm{W}\left(270^{\circ}\right)$ at the following calculated times: (a) -9 hours 30 minutes, (b) $-10 \mathrm{~h}$, (c) $-10 \mathrm{~h} 30 \mathrm{~min}$, (d) $-11 \mathrm{~h}$, (e) $-11 \mathrm{~h}$ $30 \mathrm{~min},(\mathrm{f})-12 \mathrm{~h},(\mathrm{~g})-12 \mathrm{~h} 30 \mathrm{~min},(\mathrm{~h})-13 \mathrm{~h}$, (i) - $13 \mathrm{~h} 30 \mathrm{~min},(\mathrm{j})-14 \mathrm{~h},(\mathrm{k})-14 \mathrm{~h} 30 \mathrm{~min}$, (1) $-15 \mathrm{~h}$ (completion of dredging operation). The symbol «+» indicates the current position of the dredging vessel at a predetermined design time. The dashed line shows the calculated position of the isolines, which correspond to a concentration of $\mathrm{SM}=50 \mathrm{mg} / \mathrm{L}$ for the zone of additional turbidity in water environment. 
respect to time, and the SM concentration within the spot are controlled by the rates of processes of SM deposition and transport by currents. The gravitational deposition of SM is of decisive importance.

According to calculations, the maximum SM concentrations inside the turbidity zones during the work period do not exceed 10-15 g/L. However, the turbidity spot usually remains in the water for no more than 1 hour after the completion of dredging work and loading the hold of the dredge with soil.

\subsection{Calculation of the thickness of the SM layer deposited on the bottom surface}

We will assume that for each working day, the volume and thickness of the SM layer accumulated at the bottom will be $V_{\text {sed }}\left(\mathrm{M}^{3}\right)$ and $h_{\text {sed }}(\mathrm{M})$ respectively. We also denote the area $S_{\text {sed }}\left(\mathrm{m}^{2}\right)$ on which the SM falls. This area is equal to the area with an additional concentrations of SM $(>50 \mathrm{mg} / \mathrm{L})$ with particle size $<0.14 \mathrm{~mm}$.

The volume weight of the soil $\gamma\left(\mathrm{t} / \mathrm{m}^{3}\right)$ in the natural state is equal $M_{\text {sed }} / V_{\text {sed }}$ where $M_{\text {sed }}$ is the mass of the sediment settling to the bottom (t), and $V_{\text {sed }}=S_{\text {sed }} \mathrm{x} h_{\text {sed }}$.

According to available data, $\gamma=1.52 \mathrm{t} / \mathrm{m}^{3}$. Calculations show that a result of dredging work and loading of soil into the hold of the dredge with overfilling is $46650.59 \mathrm{~g}$ of SM, and the amount of SM which enter into the water column (with depth $H$ ) every second is $46650.59 \mathrm{~g} \times 3600 \times 6=1007652744 \mathrm{~g}$ of SM (or $1007.653 \mathrm{t} \mathrm{SM}$ ). In this case, the value of $S_{\text {sed }}=207.3 \mathrm{ha} /$ day of work. Then the thickness of the layer of precipitated $\mathrm{SM}, h_{\text {sed }}$ per day, is determined by the following formula:

$$
h_{\text {sed }}=\frac{M_{\text {sed }}}{\gamma S_{\text {sed }}} .
$$

Substituting in this relation the numerical values of the parameters, we obtain

$$
h_{\text {sed }}=\frac{1007.653}{1.52 \cdot 207.3 \times 10^{4}} \approx 3.2 \times 10^{-4} \mathrm{~m} \text {. }
$$

For 180 days, as stipulated in the work plan, the thickness of the SM layer of precipitation falling to the bottom will be $3,2 \times 10^{-4} \cdot 180 \approx 0,06 \mathrm{~m}$ ( or $\left.\sim 6 \mathrm{~cm}\right)$.

The account of wave movement of waters at the performance of model calculations is made only for shallow water bodies. For similar water areas (bays, lagoons, estuaries of rivers), the account of the wave influence on the SM distribution is important because it determines the rates of SM settling and bottom sediment resuspension as well as the duration of the turbidity spots existence in the water.

To take into account the wave motion of water, according to theoretical developments (Shore protection...., 1984), the inequality $\left(Z_{w} / L_{\text {wave }}<1 / 25\right.$, where $Z_{w}$ - the depth of the section of the water body, $L_{\text {wave }}$ - the length of the wind wave) should be satisfied. In this case, the bypassing area was chosen for the coastal area of the Baltic Sea with depths of 15-30 m, for which $Z_{w} / L_{\text {wave }}>1 / 25$. Consequently the wave action factor in this case may not be taken into account in the calculations. 


\section{Conclusions}

Selection of empirical parameters of the model (or the model calibration, its testing and verification) requires the presence of appropriate data of observatios. There is an especially acute problem for the data of observations on the spatial SM distribution in the proposed area of dredging. As a rule, such data are not complete, and most often they are absent altogether. Therefore, whenever a model calculation is performed, the researcher faces a complex question about the adequacy of the model calculations performed. In this case, obviously, we can not say now about the comparison of calculation results with observations. Nevertheless, even in the lack of full-scale data, the modeling results provide a lot of useful information on the spreading suspension processes in marine coastal areas. In particular, modeling allow us quantitatively estimate the significance of various processes in the formation of the space-temporal structure of turbidity fields, and also in the calculating the damage to aquatic biological resources that can be caused as a result of dredging works.

The performed model calculations showed that for the considered coastal water area of the Baltic Sea with depths of 15-30 m, the process of formation of the turbidity spot, the duration of its presence and the SM concentrations inside the spot are determined by the rates of processes of SM deposition and its transport by currents. The gravitational deposition of SM is most significant affecting these individual processes.

Maximum SM concentrations within the turbidity zones during dredging can exceed 3-4 g/L. The total operating time of the dredger work is $6 \mathrm{~h}$, the average settling velocity is $\sim 0.65 \mathrm{sm} / \mathrm{sec}$, and the total time of its settling at different depths should be 45-85 minutes. Thus, the average time of the turbidity spot presence in the water after the completion of the dredging and the loading of the soil into the hold of the dredge does not exceed 1 hour. If we additionally take into account that the hydraulic size of the particles with a diameter of $0.05-0.1 \mathrm{~mm}$ is $\sim 0.2 \mathrm{sm} / \mathrm{sec}$, and the time of gravitational subsidence of this fraction at depths of 15-30 m will be 125-250 minutes. However, the quota of this fraction, according to the granulometric composition of SM, is only $1.6 \%$ Therefore, it can be assumed that the average residence time of the turbidity spot in the water during dredging and after their completion is $8-10$ hours.

An important result of the model calculations concerning of the SM diffusion during dredging is the possibility to estimate the thickness of the layer of SM precipitation at the falling to the bottom. This value is estimated at $6 \mathrm{~cm}$.

The work on bypassing violates the natural habitats of aquatic biological resources (in particular, benthic organisms). The obtained values of the parameters, characterizing the changing conditions for the redistribution of SM concentrations in water environment and on the bottom surface, can be used for the subsequent assessments of damage caused by dredging to aquatic biological resources.

In this paper, we show all the main necessary steps for the preparation and practical application of the developed SM-model for assessing the consequences of dredging the SM formation and its redistribution in the marine offshore area. Unfortunately, at this point in time, not all stages of the model check can be performed due to a lack of necessary observational data. Nevertheless, even these preliminary calculation results allow us to conclude that the model is operational, its capabilities to give realistic results and to conduct further assessments of the possible damage to water biological resources. Similar damage can be associated with the performance of various types of work in which some external mechanical effect on bottom sediments and the formation of additional turbidity zones in the aquatic environment is expected. 
The developed model allows to significantly expand the potential capabilities of already available mathematical models that have undergone comprehensive testing and verification, proved their efficiency, and are practically used for studying the processes of biohydrochemical transformation of biogenic substances and the dissolved oxygen dynamics in the aquatic environment. An important addition to the previous models is fact that now there is a real possibility to take into account the wind and hydrodynamic effects on the bottom sediments, the processes of SM precipitation and the bottom sediment stirring up, and also (if necessary) the processes of flocculation and/or different types of dredging.

\section{References}

Afanasyev S.V., Ryanzhin S.V., Numerical simulation of horizontal turbulent diffusion in a shallow lake, Vod. Resources, 1986, Vol. 13, No. 1, pp. 87-94, [In Russian].

Chao X., Jia Y., Shields Jr. F.D., Wang S.S.Y., et al., Three-dimensional modeling of cohesive sediment transport and wind wave impact in a shallow oxbow lake, Adv. Water Res., 2008, Vol. 31, pp. 1004-1014.

Hamilton D.P., Mitchell S.F., An empirical model for sediment resuspension in shallow lakes, Hydrobiologia, 1996, Vol. 317, pp. 209-220.

Lou J., Schwab D.J., Beletsky D., Hawley N., A model of sediment resuspension and transport dynamics in the southern Lake Michigan, J. Geophys. Res., 2000, Vol. 105, pp. 6591-6610.

Mehta A.J., Partheniades E., An investigation of the depositional properties of flocculated fine sediment, J. Hydraul. Res., 1975, Vol. 13, pp. 361-381.

Methodological guidelines for calculating the distribution of turbidity zones during dredging and dumping in the Navy. Moscow: the Ministry of Defense of the Russian Federation, 2003, 80 p., [In Russian].

Oil and the environment of the Kaliningrad region, Vol. II: The sea, ed. V.V. Sivkova, Yu.S. Kajoian, O.E. Pichuzhkina, V.N. Feldman, Kaliningrad: Terra Baltika, 2012, 576 p., [In Russian].

Poddubnyi S.A., Podgornyi K.A., Use of a two-dimensional mathematical model for studying the thermal regime of the Rybinsk Reservoir, Proceedings of the VII Conference "Dynamics and Thermal of Rivers, Reservoirs and the Coastal Zone of the Seas" (Moscow, November 23-25, 2009) - Moscow: PFUR, 2009, pp. 216-224, [In Russian].

Podgornyi K.A., Mathematical modeling of spatial-temporal dynamics of current fields in the Neva Bay, the Gulf of Finland. Proceedings of the $2^{\text {nd }}$ International Conference (school) on Dynamics of Coastal Zone of Non-Tidal Seas. Baltiysk (Kaliningrad Oblast), 26-30 June 2010 / Ed. by B. Chubarenko, Kaliningrad: Terra Baltica, 2010, pp. 225-231.

Podgornyi K.A., Mathematical modeling of transformation of biogenic elements substances in ecosystems of non-stratified reservoirs, Dissirtation of candidate of phys.-mathem. sciences: 03.01.02, 25.00.28, Moscow, 2012, 488 p., [In Russian].

Podgornyi K.A., Modeling of the thermal regime of the Rybinsk Reservoir, Materials of the V International Scientific Conference "Theoretical and Applied Aspects of Modern Limnology" (Minsk, November 10-13, 2009), Minsk: Belarus State University, 2009a, pp. 90-93, [In Russian].

Podgornyi K.A., Simulation of the space-temporal dynamics of water temperature fields in the Neva Bay of the Gulf of Finland. Proceedings of the VII Conference "Dynamics and Thermal of Rivers, Reservoirs and the Coastal Zone of the Seas" (Moscow, November 23-25, 2009), Moscow: RUDN, 2009b, pp. 207-215.

Podgornyi K.A., Leonov A.V., Modeling of the processes of distribution of suspended matter in marine coastal areas: 1. Description of the SM-model, Journal of Oceanological Research, 2017, Vol. 45, No. 1, pp. 109-141, DOI: 10.29006/1564-2291.JOR-2017.45(1).10.

Podgornyi K.A., Poddubnyi S.A., Modeling of the formation and intra-annual variability of the 
flow structure in the estuarine zone of the Rybinsk Reservoir, Proceedings of the V International Scientific Conference "Theoretical and Applied Aspects of Contemporary Limnology” (Minsk. November 10-13. 2009), Minsk: Belarus State University, 2009, pp. 97-100, [In Russian].

Podgornyi K.A., Poddubnyi S.A., Use of the system of equations of the theory of shallow water for the modeling of currents in the Rybinsk Reservoir.Proceedings of the All-Russian Scientific and Practical Conference (Perm'. May 24-26. 2005), Perm': Perm' University, 2005, pp. 62-66, [In Russian].

Shore protection manual, U.S. Army engineer waterways experimental station, Coastal engineering research centre, V. I, $4^{\text {th }}$ edition, PO Box 631, Vicksburg, Mississippi 39180, 1984, 652 p.

Stanev E.V., Dobrynin M., Pleskachevsky A., Grayek S., et al., Bed shear stress in the southern North Sea as an important driver for suspended sediment dynamics, Ocean Dynamics, 2009, Vol. 59, pp. 183-194.

Ziegler C.K., Nisbet B.S., Long-term simulation of fine-grained sediment transport in large reservoir, J. Hydraul. Eng., 1995, Vol. 121, pp. 773-781.

\title{
МОДЕЛИРОВАНИЕ ПРОЦЕССОВ РАСПРОСТРАНЕНИЯ ВЗВЕШЕННОГО ВЕЩЕСТВА В МОРСКИХ ПРИБРЕЖНЫХ АКВАТОРИЯХ: \\ 2. ТЕСТИРОВАНИЕ И ПРАКТИЧЕСКОЕ ПРИМЕНЕНИЕ ВВ-МОДЕЛИ
}

\author{
К. А. Подгорный ${ }^{1}$, А. В. Леонов ${ }^{2}$ \\ IАтлантический НИИ рыбного хозяйства и океанографии, \\ 236000 , г. Калининград, ул. Дм. Донского, д. 5, \\ e-mail: kapborok@mail.ru \\ ${ }^{2}$ Институт океанологии им. П.П. Ширшова РАН, 117997, Москва, \\ Нахимовский проспект, д. 36, e-mail: leonov@ocean.ru. \\ Статья поступила в редакцию 05.09.2017, одобрена к печати 25.12.2017
}

\begin{abstract}
Показано применение разработанной модели, описывающей последствия дноуглубительных работ в прибрежных акваториях (формирование в воде пятна мутности ираспространения взвешенноговеществапоакватории), атакжевычисляющей значения ряда параметров, характеризующих условия перераспределения взвешенного вещества в толще воды и на поверхности дна. К таким параметрам относятся продолжительность присутствия в воде пятна мутности, изменения и распределения концентрации взвешенного вещества внутри такого пятна и накопления потерь взвешенного вещества на дне за весь период работ. Эти параметры входят в перечень характеристик, на основе которых оценивается ущерб биоресурсам (например, бентосным организмам) за счет нарушений естественных условий их обитания после завершения работ по байпассингу.
\end{abstract}

Ключевые слова: байпассинг; модель распространения взвешенного вещества; учитываемые природные факторы (ветер, морские течения, температура и соленость морской воды, свойства песчаных донных отложений); технологические данные проведения дноуглубительных работ; расчеты потерь грунта, условия образования взвешенного вещества, его концентрация в воде, аккумуляция на дне

\section{Литература}

Афанасьев С.В., Рянжин С.В. Численное моделирование горизонтальной турбулентной диффузии в мелком озере // Вод.ресурсы. 1986. Т. 13. № 1. С. 87-94.

Методические указания по расчету распространения зон мутности при дноуглублении и дампинге на акваториях ВМФ. М.: МО РФ, 2003. 80 с. 
Нефть и окружающая среда Калининградской области. Т. II: Море / под ред. В.В. Сивкова, Ю.С. Каджояна, О.Е. Пичужкиной, В.Н. Фельдмана. Калининград: Терра Балтика, 2012. $576 \mathrm{c}$.

Подгорный K.A. Моделирование термического режима Рыбинского водохранилища // Материалы V Международной научной конференции «Теоретические и прикладные аспекты современной лимнологии» (г. Минск, 10-13 ноября 2009 г.). Минск: БГУ, 2009a. C. 90-93.

Подгорный К.А. Моделирование пространственно-временной динамики полей температуры воды в Невской губе Финского залива // Труды VII конференции «Динамика и термика рек, водохранилищ и прибрежной зоны морей» (г. Москва, 23-25 ноября 2009 г.) М.: РУДН, 2009б. С. 207-215.

Подгорный K.A. Математическое моделирование трансформации соединений биогенных элементов в экосистемах нестратифицированных водоемов. Дис... канд. физ.-мат. наук: 03.01.02, 25.00.28. М., 2012. 488 c.

Подгорный К.А., Леонов А.В. Моделирование процессов распространения взвешенного вещества в морских прибрежных акваториях. I. Описание модели // Океанологические исследования. 2017. Т. 45. № 1. C. 109-141. DOI: 10.29006/1564-2291. JOR-2017.45(1).10.

Подгорный K.A., Поддубный С.А. Использование системы уравнений теории мелкой воды для моделирования течений в Рыбинском водохранилище // Материалы Всероссийской научно-практической конференции (г. Пермь, 24-26 мая 2005 г.). Пермь: Перм. ун-т, 2005. С. 62-66.

Подгорный К.А., Поддубный С.А. Моделирование формирования и внутригодовой изменчивости структуры течений в устьевой зоне Рыбинского водохранилища // Материалы V Международной научной конференции «Теоретические и прикладные аспекты современной лимнологии» (г. Минск, 10-13 ноября 2009 г.). Минск: БГУ, 2009. C. 97-100.

Поддубный С.А., Подгорный К.А. Использование двумерной математической модели для изучения термического режима Рыбинского водохранилища // Труды VII конференции «Динамика и термика рек, водохранилищ и прибрежной зоны морей» (г. Москва, 2325 ноября 2009 г.). М.: РУДН, 2009. С. 216-224.

Chao X., Jia Y., Shields Jr. F.D., Wang S.S.Y., et al. Three-dimensional modeling of cohesive sediment transport and wind wave impact in a shallow oxbow lake // Adv. Water Res. 2008. Vol. 31. P. 1004-1014.

Hamilton D.P., Mitchell S.F. An empirical model for sediment resuspension in shallow lakes // Hydrobiologia. 1996. Vol. 317. P. 209-220.

Lou J., Schwab D.J., Beletsky D., Hawley N. A model of sediment resuspension and transport dynamics in southern Lake Michigan // J. Geophys. Res. 2000. Vol. 105. P. 6591-6610.

Mehta A.J., Partheniades E. An investigation of the depositional properties of flocculated fine sediment // J. Hydraul. Res. 1975. Vol. 13. P. 361-381.

Podgornyj K.A. Mathematical modeling of spatial-temporal dynamics of current fields in the Neva Bay, the Gulf of Finland // Proceedings of the 2nd International Conference (school) on Dynamics of Coastal Zone of Non-Tidal Seas. Baltiysk (Kaliningrad Oblast), 26-30 June 2010 / Ed. by B. Chubarenko. Kaliningrad: Terra Baltica, 2010. P. 225-231.

Shore protection manual. U.S. Army engineer waterways experimental station. Coastal engineering research centre. Vol. I, 4th edition. PO Box 631, Vicksburg, Mississippi 39180. 1984. 652 p.

Stanev E.V., Dobrynin M., Pleskachevsky A., Grayek S., et al. Bed shear stress in the southern North Sea as an important driver for suspended sediment dynamics // Ocean Dynamics. 2009. Vol. 59. P. 183-194.

Ziegler C.K., Nisbet B.S. Long-term simulation of fine-grained sediment transport in large reservoir // J. Hydraul. Eng. 1995. Vol. 121. P. 773-781. 